\title{
Estimates of heritability and genetic correlations for meat quality traits in broilers
}

\author{
Leila de Genova Gaya ${ }^{1}$, Gerson Barreto Mourão², José Bento Sterman Ferraz ${ }^{3}$, Elisângela \\ Chicaroni de Mattos ${ }^{3}$, Andrezza Marcovig Moreira Alves da Costa ${ }^{3}$, Tércio Michelan Filho ${ }^{4}$, \\ Alessandra Fernandes Rosa ${ }^{3}$, Andrezza Maria Felício ${ }^{2}$, Joanir Pereira Eler ${ }^{3}$ \\ ${ }^{1}$ UFS - Depto. de Engenharia de Biossistemas, Pça. Dom Helvécio, 74 - 36301-160 - São João del-Rei, MG - Brasil. \\ ${ }^{2}$ USP/ESALQ - Depto. de Zootecnia, C.P. 09 - 13418-900 - Piracicaba, SP - Brasil. \\ ${ }^{3}$ USP/FZEA - Av. Duque de Caxias Norte, 225 - 13635-970 - Pirassununga, SP - Brasil. \\ ${ }^{4}$ Aviagen do Brasil Ltda., Rod. SP 127, km 2,2 - 13500-970 - Rio Claro, SP - Brasil. \\ *Corresponding author <lggaya@yahoo.com.br> \\ Edited by: Luís Reynaldo Ferracciú Alleoni
}

\begin{abstract}
Broiler meat quality is one of the primary factors considered by the poultry industry. This study was conducted to estimate heritability and genetic correlation coefficients for meat quality traits in a single male broiler line. The meat ultimate $\mathrm{pH}$ (24 h after slaughter) and lightness presented the highest heritability estimates. Given the estimated genetic correlations, the $\mathrm{pH}$ measured at $15 \mathrm{~min}$ and $24 \mathrm{~h}$ after slaughtering, as well as lightness, were characterized by a close and negative genetic relationship with water holding capacity traits. In contrast, meat quality traits exhibited only non-significant genetic correlations with performance and carcass traits. Noticed exceptions were breast weight, which was genetically and favorably associated with the initial $\mathrm{pH}$ and thawing-cooking losses, and ultrasound record of pectoral muscle depth, which was genetically and unfavourably associated with the shear force of meat. Meat $\mathrm{pH}$ values at $24 \mathrm{~h}$ after slaughtering or lightness may be a favorable selection criterion for the poultry industry for improving meat quality, since these traits are associated with the water holding capacity of the meat. Out of the traits studied, lightness is most easily assessed on the industrial slaughtering line. The direct selection for breast weight could improve the initial $\mathrm{pH}$ and thawing-cooking losses of meat, even as selection for ultrasound records of Pectoralis major may affect the meat tenderness in this line.
\end{abstract}

Keywords: animal breeding, genetic parameters, poultry

\section{Introduction}

The Brazilian broiler production industry has experienced substantial progress in the last few decades. In the last years, broiler production in Brazil grew more than $40 \%$, reaching more than 11 million tons in 2008 (Avisite, 2010). This development was mainly due to the intense selection process initiated with the use of crossbreeding in poultry production. However, the selection for economic traits, especially growth rate, may induce several changes in broiler meat quality (Dransfield and Sosnicki, 1999), which has been recognized as one of the main factors to be considered by the poultry industry because changes in meat quality could lead to substantial economical losses.

Broiler meat quality is influenced by several factors, such as pre-slaughter handling, muscle size, stunning, carcass chilling and aging, but is mainly affected by genetics (Solomon et al., 1998; Sams, 1999). It is therefore necessary to estimate the heritability of meat quality traits in order to evaluate the possibility of direct selection on these traits. The estimation of genetic correlations between meat quality traits and other traits commonly used as selection criteria in animal breeding programs would help to anticipate how a direct selection would influence other traits, or conversely, how previous selection has affected meat quality. Because measuring these traits is a complex process and involves the slaughter of animals, studies of these parameters in poultry are rare in literature (Le Bihan-Duval et al., 1999, 2001, 2003, 2008).
Thus, this study aimed at estimating the heritability and the genetic correlation coefficients for meat quality, performance, and carcass traits in a single male broiler line. Its results could enable the characterization of the meat quality in the male line studied and the identification of the selection criteria associated with broiler meat quality.

\section{Materials and Methods}

Sibs from an elite flock that had undergone selection for development of a male line were used, which was selected to emphasize performance and carcass traits. Pedigree chicks were wing banded at hatching and housed and raised as recommended by the company guidelines for nutritional planning, management conditions and vaccination on a breeder unit. For the collection of data pertaining to performance, carcass, and meat quality traits, 13 flocks were used between Apr. 2005 and Mar. 2006. These flocks corresponded to 13 hatches from the same farm in different periods. Additionally, other data for the performance and carcass traits of broilers from this male line that had been collected previously were incorporated to the dataset. The final dataset was comprised of 504 sires and 3,975 dams.

On the breeder unit, at $30 \mathrm{~d}$ of age, an ultrasound record of the average of the pectoral muscle depth in the longitudinal and transversal directions (US) was taken from the sib test flocks. From May 2005 to Mar. 2006, each flock of sibs at 44 d of age was transported to Pirassununga, São Paulo, Brazil, to 
measure the meat quality and carcass for a total of 13 slaughters. The broilers were submitted to a minimum of $10 \mathrm{~h}$ of feed withdrawal prior to slaughter and were held in transportation crates. The transportation of the broilers to the processing plant occurred during the night and lasted about $6 \mathrm{~h}$ and they were allowed to rest about $2 \mathrm{~h}$ before slaughtering. The processing plant was semi-industrial. The voltage used for electric shock in the stunning of the broilers was $40 \mathrm{~V}$, at $60 \mathrm{~Hz}$ and an average of $45 \mathrm{~mA}$ per bird, for $9 \mathrm{~s}$. Processing speed was carried out to allow adequate time to perform all measurements. The bleeding of the broilers lasted $3 \mathrm{~min}$. Prior to feather removal, the broilers were immersed in water at $57^{\circ} \mathrm{C}$ for $2 \mathrm{~min}$. After evisceration, the carcasses were chilled at $0-4{ }^{\circ} \mathrm{C}$ within water and ice before stored at $0-2{ }^{\circ} \mathrm{C}$ for $24 \mathrm{~h}$ and then deboned. Meat quality data from the sib test flock were all measured in the Pectoralis major muscle and collected as follows.

The internal meat $\mathrm{pH}$ and temperature were measured inserting the electrode approximately $5 \mathrm{~mm}$ into the cranial portion of the right side of the muscle, at $15 \mathrm{~min}\left(\mathrm{pH}_{\mathrm{i}}\right)$ and at $6 \mathrm{~h}\left(\mathrm{pH}_{6}\right)$, directly on carcass, and at $24 \mathrm{~h}$ on deboned and skinless breast $\left(\mathrm{pH}_{\mathrm{u}}\right)$ after slaughtering using a digital pHmeter (Fernandez et al., 2002). After $\mathrm{pH}_{\mathrm{i}}$ measurement, the carcasses were submitted to pre-chilling by immersion in cold water at 10 ${ }^{\circ} \mathrm{C}$ for $10 \mathrm{~min}$ and were stored afterward in cooling chambers $\left(0-2{ }^{\circ} \mathrm{C}\right)$. The initial range of $\mathrm{pH}$ fall $\left(\mathrm{R}_{\mathrm{i}}\right)$ was calculated as the difference between $\mathrm{pH}_{\mathrm{i}}$ and $\mathrm{pH}_{6}$. Final range of $\mathrm{pH}$ fall $\left(\mathrm{R}_{\mathrm{f}}\right)$ was calculated as the difference between $\mathrm{pH}_{\mathrm{i}}$ and $\mathrm{pH}_{\mathrm{u}}$.

The color parameters were measured at $24 \mathrm{~h}$ after slaughtering using a portable colorimeter and the $\mathrm{L}^{*}$ (lightness), a* (redness) and $b^{*}$ (yelowness) scale from the CIELab system (Comission International de l'Eclairage, 1976). The measurements were recorded at three points on the muscle, on the ventral surface of the right side of the sample, and the mean of these three points was considered the determined value.
Measured Water holding capacity (WHC) were drip loss (weight loss during chill storage), thawing and thawing-cooking losses. For these measurements, Pectoralis major samples from the right side of the muscle were collected at $24 \mathrm{~h}$ after slaughtering and weighed to provide the initial breast weight (W1). These samples were then stored in a net placed in a plastic bag at $0-2{ }^{\circ} \mathrm{C}$ and reweighed after $24 \mathrm{~h}$ (W2). Other Pectoralis major samples were collected from the right side of the muscle at $24 \mathrm{~h}$ after slaughter and weighed to provide another initial breast weight (W3); these samples were frozen at $-18{ }^{\circ} \mathrm{C}$, defrosted at $4{ }^{\circ} \mathrm{C}$ and weighed (W4). These samples were cooked in an electric oven (Luxo Classic 2.4 , Lary) preheated at $170{ }^{\circ} \mathrm{C}$ until the internal temperature reached $72{ }^{\circ} \mathrm{C}$, measured by internal thermocouples, and weighed (W5). Drip, thawing and thawing-cooking losses (DL, TL, TCL) were calculated as follows: DL = (W1-W2)/W1 (Honikel, 1998); $\mathrm{TL}=(\mathrm{W} 3-\mathrm{W} 4) / \mathrm{W} 3$ (Galobart and Moran, 2004); TCL = (W4W5)/W4 (Bressan and Beraquet, 2004).

Shear force was determined using the same samples that were used for the measurements of thawing-cooking losses, which, after being cooked and cooled, were submitted to Warner Bratzler shear test. Four parallelepipeds measuring $20 \times 20 \times 10$ $\mathrm{mm}$ were removed from each breast sample, and sheared by the blade of a Warner Bratzler device. The mean of the shear force for the four parallelepipeds was taken as the sample shear force $(\mathrm{SF})$, given in kgf. The samples were positioned perpendicularly to the blade.

Other data collected from the sib test flock were: slaughter body weight (SBW), hot eviscerated carcass weight without neck and feet (EBW), breast weight without skin (BRT), and leg weight (LEG), all at $44 \mathrm{~d}$ of age.

The outliers were removed from the dataset prior to the analysis and the descriptive statistics were calculated by PROC MEANS feature of the SAS software (SAS Institute, 1999) (Table 1). Genetic parameters were obtained by restricted maximum

Table 1 - Descriptive statistics for meat quality, performance and carcass traits.

\begin{tabular}{|c|c|c|c|c|c|c|}
\hline Traits $^{1}$ & $\mathrm{~N}$ & Mean & $\mathrm{SD}^{2}$ & $\mathrm{CV}^{3}$ & Minimum & Maximum \\
\hline $\mathrm{pH}_{\mathrm{i}}$ & 938 & 6.12 & 0.19 & 3.02 & 5.64 & 6.62 \\
\hline $\mathrm{pH}_{\mathrm{u}}$ & 2107 & 5.80 & 0.13 & 2.32 & 5.44 & 6.20 \\
\hline $\mathrm{R}_{\mathrm{i}}$ & 618 & 0.26 & 0.16 & 61.06 & 0.01 & 0.78 \\
\hline $\mathrm{R}_{\mathrm{f}}$ & 777 & 0.32 & 0.15 & 46.05 & 0.01 & 0.59 \\
\hline $\mathrm{L}^{*}$ & 2130 & 56.07 & 3.00 & 5.30 & 47.62 & 63.98 \\
\hline$a^{*}$ & 2116 & 5.35 & 1.10 & 20.59 & 2.26 & 8.54 \\
\hline $\mathrm{b}^{*}$ & 2098 & 13.59 & 2.12 & 15.59 & 7.77 & 19.20 \\
\hline DL (\%) & 2030 & 2.06 & 0.58 & 28.21 & 0.30 & 3.70 \\
\hline TL (\%) & 2125 & 6.46 & 3.22 & 49.82 & 0.40 & 18.30 \\
\hline TCL (\%) & 2122 & 21.26 & 4.17 & 19.62 & 8.80 & 32.60 \\
\hline $\mathrm{SF}(\mathrm{kg})$ & 2113 & 1.21 & 0.41 & 33.94 & 0.30 & 2.50 \\
\hline US (mm) & 28155 & 25.40 & 2.93 & 11.55 & 17.50 & 33.50 \\
\hline SBW (g) & 15950 & 2656.11 & 395.51 & 14.89 & 1408.00 & 3874.00 \\
\hline EBW (g) & 15949 & 1869.91 & 286.18 & 15.30 & 960.00 & 2776.00 \\
\hline BRT (g) & 15868 & 512.93 & 89.47 & 17.44 & 245.00 & 770.00 \\
\hline LEG (g) & 1945 & 647.17 & 114.23 & 17.65 & 294.00 & 986.00 \\
\hline
\end{tabular}

${ }^{1} \mathrm{pH}_{\mathrm{i}}=$ initial $\mathrm{pH} ; \mathrm{pH}_{\mathrm{u}}=$ ultimate $\mathrm{pH} ; \mathrm{R}_{\mathrm{i}}=$ initial range of $\mathrm{pH}$ fall; $\mathrm{R}_{\mathrm{f}}=$ final range of $\mathrm{pH}$ fall; $\mathrm{L}^{*}=$ lightness; $\mathrm{a}^{*}=$ redness; $\mathrm{b}^{*}=$ yellowness; $\mathrm{DL}=$ drip loss; $\mathrm{TL}=$ thawing loss; $\mathrm{TCL}=$ thawing-cooking loss; $\mathrm{SF}=$ shear force; $\mathrm{US}=$ ultrasound record of pectoral muscle depth; $\mathrm{SBW}=$ slaughter BW; EBW = eviscerated BW; BRT = breast weight; $\mathrm{LEG}=$ leg weight. ${ }^{2} \mathrm{SD}=$ standard-deviation. ${ }^{3} \mathrm{CV}=$ coefficient of variation. 
likelihood (REML) method using an animal model and the VCE software (Groeneveld, 1997). The numerator relationship matrix had 107,154 animals, distributed into six generations. The following mathematic model was used: $\mathbf{y}=\mathbf{X b}+\mathbf{Z u}+\mathbf{e}$, where $\mathbf{y}$ is the dependent variables vector; $\mathbf{X}$ is the fixed effects incidence matrix, associating elements from $\mathbf{b}$ to $\mathbf{y} ; \mathbf{b}$ is the fixed effects vector; $\mathbf{Z}$ is the random effects incidence matrix, associating elements from $\mathbf{u}$ to $\mathbf{y}$; $\mathbf{u}$ is the random effect vector, considered as the direct additive genetic effect; and $\mathbf{e}$ is the residual effects vector. The random maternal genetic effect was also considered in the model for all traits. The shown heritability coefficients for meat quality traits were those obtained in the two-trait analysis with US, which was the reference trait, due to the fact that it had the highest number of observations.

The considered fixed effects were the contemporary groups for each analyzed trait. The significance of the effects for the traits studied was estimated by the PROC GLM feature of the SAS software (SAS Institute, 1999), and found to be significant ( $p$ $<0.05)$. The effects tested for each trait were hatch (52 levels), sex (2 levels), and dam age (11 levels). Hatch effects were significant and included in the contemporary groups for all traits. Sex was significant and included for all traits except $\mathrm{pH}_{\mathrm{i}}, \mathrm{pH}_{\mathrm{u}}, \mathrm{R}_{\mathrm{i}}, \mathrm{R}_{\mathrm{f}}, \mathrm{a}^{*}$, and $b^{*}$. Maternal age was included for US, SBW, and EBW only because these effects were not significant for the other traits.

\section{Results and Discussion}

The heritability estimates of meat quality traits were low to moderate in this broiler line (estimates ranging from 0.06 to 0.31, as presented in Table 2). $\mathrm{pH}_{\mathrm{u}}$ and $\mathrm{L}^{*}$ exhibited the highest heritability estimates among meat quality traits $(0.31 \pm 0.024$ and $0.29 \pm 0.044$, respectively). $R_{i}, a^{*}, T L, T C L$ and SF were moderately to minimally heritable $(0.20 \pm 0.034$ to $0.24 \pm 0.027)$, and the heritability estimates for $\mathrm{pH}_{\mathrm{i}}, \mathrm{R}_{\mathrm{f}}, \mathrm{b}^{*}$ and $\mathrm{DL}(0.06 \pm 0.039$ to $0.12 \pm 0.034$ ) were low.
The direct heritability estimated for $\mathrm{pH}_{\mathrm{i}}(0.07 \pm 0.058)$ was lower than those described for broilers and turkeys (Le BihanDuval et al., 2001, 2003) and the direct heritability estimate for $\mathrm{pH}_{\mathrm{u}}(0.31 \pm 0.024)$ was similar to that reported for broilers (Le Bihan-Duval et al., 2001). Direct additive genetic effects seemed to exist in the expression of $\mathrm{pH}_{\mathrm{u}}$; nevertheless, for $\mathrm{pH}_{\mathrm{i}}$, there was no direct additive genetic effect. The heritability estimate for the $R_{f}(0.06 \pm 0.039)$ was not suggestive of a direct additive genetic effect controlling this trait, although $R_{i}(0.23 \pm 0.095)$ presented with a moderate to low direct additive genetic effect.

For $\mathrm{L}^{*}$ and $\mathrm{b}^{*}$, the direct heritability estimates $(0.29 \pm 0.044$ and $0.12 \pm 0.034$, respectively) were lower than that reported in broilers (Le Bihan-Duval et al., 1999, 2001, 2008). The direct heritability estimate for $a^{*}(0.24 \pm 0.027)$ was similar or lower than those presented for broilers (Le Bihan-Duval et al., 1999, 2001, 2008). Based on these estimates, it seems that direct selection would be effective in improving $\mathrm{L}^{*}$, which is the primary parameter for meat color in broilers. The direct heritability estimate for DL $(0.09 \pm 0.036)$ was lower than that reported in broilers for this trait (Le Bihan-Duval et al., 2001), suggesting low, direct additive genetic factors influencing the expression of this trait, and moderate to low direct heritability estimates were found for TL, TCL and SF $(0.23 \pm 0.043,0.21 \pm 0.037$, and $0.20 \pm 0.034$, respectively). Hence, $\mathrm{pH}_{\mathrm{u}}$ and $\mathrm{L}^{*}$ had higher direct additive genetic effects among the traits studied, which indicated that these traits could respond to selection because their expression is more dependent on additive genetic effects, while the expression of the other traits is more dependent on non-additive genetic effects and environmental conditions. In this study, $\mathrm{pH}_{\mathrm{i}}$ and $\mathrm{R}_{\mathrm{i}}$ were not dependent on the additive genetic effects and their expression were possibly mainly due to environmental effects, in contrast with the other studies (Anthony, 1998; Sams, 1999), in which the initial pH decrease has been reported as a consequence of genetic effects. Thus, direct selection to modify these traits may be efficient, for use

Table 2 - Estimates of heritability (in bold, on the diagonal) and genetic correlations for meat quality traits.

\begin{tabular}{|c|c|c|c|c|c|c|c|c|c|c|c|}
\hline Traits $^{1}$ & $\mathrm{pH}_{\mathrm{i}}$ & $\mathrm{pH}_{\mathrm{u}}$ & $\mathrm{R}_{\mathrm{i}}$ & $\mathrm{R}_{\mathrm{f}}$ & $\mathrm{L}^{*}$ & $a^{*}$ & $b^{*}$ & DL & TL & TCL & SF \\
\hline $\mathrm{pH}_{\mathrm{i}}$ & $\begin{array}{r}0.07 \pm \\
0.058\end{array}$ & & & & & & & & & & \\
\hline $\mathrm{pH}_{\mathrm{u}}$ & $\begin{array}{r}0.52 \pm \\
0.170\end{array}$ & $\begin{array}{l}0.31 \pm \\
0.024\end{array}$ & - & - & - & - & - & - & - & - & \\
\hline $\mathrm{R}_{\mathrm{i}}$ & $\begin{array}{r}-0.64 \pm \\
0.316\end{array}$ & $\begin{array}{l}-0.73 \pm \\
0.170\end{array}$ & $\begin{array}{r}0.23 \pm \\
0.095\end{array}$ & - & - & - & - & - & - & - & \\
\hline$R_{f}$ & $\begin{array}{r}0.40 \pm \\
0.325\end{array}$ & $\begin{array}{c}-0.58 \pm \\
0.744\end{array}$ & $\begin{array}{r}-0.46 \pm \\
0.849\end{array}$ & $\begin{array}{r}0.06 \pm \\
0.039\end{array}$ & - & - & - & - & - & - & \\
\hline $\mathrm{L}^{*}$ & $\begin{array}{r}-0.11 \pm \\
0.052\end{array}$ & $\begin{array}{c}-0.41 \pm \\
0.108\end{array}$ & $\begin{array}{r}0.67 \pm \\
0.237\end{array}$ & $\begin{array}{r}-0.57 \pm \\
0.572\end{array}$ & $\begin{array}{r}0.29 \pm \\
0.044\end{array}$ & - & - & - & - & - & \\
\hline$a^{*}$ & $\begin{array}{r}-0.51 \pm \\
0.168\end{array}$ & $\begin{array}{c}-0.38 \pm \\
0.130\end{array}$ & $\begin{array}{r}0.16 \pm \\
0.061\end{array}$ & $\begin{array}{r}0.02 \pm \\
0.117\end{array}$ & $\begin{array}{r}-0.32 \pm \\
0.121\end{array}$ & $\begin{array}{r}0.24 \pm \\
0.027\end{array}$ & - & - & - & - & \\
\hline$b^{*}$ & $\begin{array}{r}-0.13 \pm \\
0.234\end{array}$ & $\begin{array}{c}-0.25 \pm \\
0.062\end{array}$ & $\begin{array}{r}0.49 \pm \\
0.234\end{array}$ & $\begin{array}{r}-0.11 \pm \\
0.140\end{array}$ & $\begin{array}{r}0.34 \pm \\
0.151\end{array}$ & $\begin{array}{r}0.17 \pm \\
0.162\end{array}$ & $\begin{array}{r}0.12 \pm \\
0.034\end{array}$ & - & - & - & \\
\hline DL & $\begin{array}{r}-0.40 \pm \\
0.089\end{array}$ & $\begin{array}{c}-0.69 \pm \\
0.132\end{array}$ & $\begin{array}{r}0.68 \pm \\
0.224\end{array}$ & $\begin{array}{r}0.80 \pm \\
1.208\end{array}$ & $\begin{array}{r}0.20 \pm \\
0.174\end{array}$ & $\begin{array}{r}0.48 \pm \\
0.155\end{array}$ & $\begin{array}{r}0.16 \pm \\
0.212\end{array}$ & $\begin{array}{r}0.09 \pm \\
0.036\end{array}$ & - & - & \\
\hline TL & $\begin{array}{r}-0.75 \pm \\
0.125\end{array}$ & $\begin{array}{l}-0.83 \pm \\
0.075\end{array}$ & $\begin{array}{r}0.26 \pm \\
0.246\end{array}$ & $\begin{array}{r}-0.54 \pm \\
0.469\end{array}$ & $\begin{array}{r}0.37 \pm \\
0.093\end{array}$ & $\begin{array}{r}0.46 \pm \\
0.130\end{array}$ & $\begin{array}{r}-0.02 \pm \\
0.163\end{array}$ & $\begin{array}{r}0.91 \pm \\
0.072\end{array}$ & $\begin{array}{r}0.23 \pm \\
0.043\end{array}$ & - & \\
\hline TCL & $\begin{array}{r}-0.58 \pm \\
0.169\end{array}$ & $\begin{array}{c}-0.42 \pm \\
0.128\end{array}$ & $\begin{array}{r}-0.01 \pm \\
0.270\end{array}$ & $\begin{array}{r}0.51 \pm \\
0.095\end{array}$ & $\begin{array}{r}0.40 \pm \\
0.101\end{array}$ & $\begin{array}{r}0.00 \pm \\
0.151\end{array}$ & $\begin{array}{r}0.05 \pm \\
0.178\end{array}$ & $\begin{array}{r}0.51 \pm \\
0.170\end{array}$ & $\begin{array}{r}0.74 \pm \\
0.057\end{array}$ & $\begin{array}{r}0.21 \pm \\
0.037\end{array}$ & \\
\hline SF & $\begin{array}{r}-0.62 \pm \\
0.170\end{array}$ & $\begin{array}{c}-0.63 \pm \\
0.094\end{array}$ & $\begin{array}{r}0.20 \pm \\
0.084\end{array}$ & $\begin{array}{r}-0.34 \pm \\
0.723\end{array}$ & $\begin{array}{r}0.59 \pm \\
0.113\end{array}$ & $\begin{array}{r}0.18 \pm \\
0.129\end{array}$ & $\begin{array}{r}0.10 \pm \\
0.167\end{array}$ & $\begin{array}{r}0.68 \pm \\
0.134\end{array}$ & $\begin{array}{r}0.67 \pm \\
0.070\end{array}$ & $\begin{array}{r}0.51 \pm \\
0.095\end{array}$ & $\begin{array}{r}0.20 \pm \\
0.034\end{array}$ \\
\hline
\end{tabular}

${ }^{1} \mathrm{pH}_{\mathrm{i}}=$ initial $\mathrm{pH} ; \mathrm{pH}_{\mathrm{u}}=$ ultimate $\mathrm{pH} ; \mathrm{R}_{\mathrm{i}}=$ initial range of $\mathrm{pH}$ fall; $\mathrm{R}_{\mathrm{f}}=$ final range of $\mathrm{pH}$ fall; $\mathrm{L}^{*}=$ lightness; $\mathrm{a}^{*}=$ redness; $\mathrm{b}^{*}=$ yellowness; $\mathrm{DL}=$ drip loss; $\mathrm{TL}=$ thawing loss; $\mathrm{TCL}=$ thawing-cooking loss; $\mathrm{SF}=$ shear force. 
as selection criteria to improve meat quality. $\mathrm{R}_{\mathrm{i}}, \mathrm{a}^{*}$, TL, TCL and SF could also be responsive to selection, although at lower levels than those expected for $\mathrm{pH}_{\mathrm{u}}$ and $\mathrm{L}^{*}$. Because $\mathrm{pH}_{\mathrm{i}}$ and $\mathrm{R}_{\mathrm{i}}$ did not present important direct additive genetic variance, PSE could not be developed by the additive genetic influence of the initial $\mathrm{pH}$ in the studied male broiler line, and these traits could not be used to avoid the PSE condition (pale, soft, exudative meat) (Barbut, 1997).

The significance of the genetic correlation estimates among the analyzed traits was variable (Tables 2 and 3). The genetic correlation estimate between $\mathrm{pH}_{\mathrm{i}}$ and $\mathrm{pH}_{\mathrm{u}}$ was high and positive $(0.52 \pm 0.170)$. The estimate for $\mathrm{pH}_{\mathrm{i}}$ and $\mathrm{pH}_{\mathrm{u}}$ is higher than that reported in turkeys (Le Bihan-Duval et al., 2003). Nevertheless, these results diverged from those reported in broilers (Le Bihan-Duval et al., 2001), in which initial and ultimate meat $\mathrm{pH}$ measures were not genetically associated. Genetic correlation estimates near zero among these traits are reported in pigs (Larzul et al., 1999), which could be attributed to independent control mechanisms for initial and ultimate $\mathrm{pH}$. This possibility was not verified by the current study, in which a decrease in $\mathrm{pH}_{\mathrm{i}}$ seemed to be able to induce to a decrease in $\mathrm{pH}_{\mathrm{u}}$, suggesting that the same genes could be involved with the control of both traits.

$\mathrm{L}^{*}$ was moderately and inversely correlated with $\mathrm{pH}_{\mathrm{u}}$ ( $\mathrm{rg}$ $-0.41 \pm 0.108)$, whereas $\mathrm{a}^{*}$ was associated with $\mathrm{pH}_{\mathrm{i}}$ and $\mathrm{pH}_{\mathrm{u}}$ (rg $-0.51 \pm 0.168$ and $-0.38 \pm 0.130$, respectively). Otherwise, as already reported (Le Bihan-Duval et al., 1999, 2001, 2008), $\mathrm{pH}_{\mathrm{i}}$ and $\mathrm{pH}_{\mathrm{u}}$ was inversely or minimally associated with color parameters, at variable intensities, in broilers. Lower $\mathrm{pH}_{\mathrm{i}}$ should be related with higher $\mathrm{L}^{*}$ because meat lightness must be proportional to the surface water content, which is antagonistically associated with meat $\mathrm{pH}$ decreases just after slaughtering. Perhaps very low, initial meat $\mathrm{pH}$ is able to cause protein denaturation and consequently reduce the water holding capacity of meat, increasing the amount of water on its surface and consecutively its lightness (Le Bihan-Duval, 2004). Nevertheless, this association was not found in the current study because initial meat $\mathrm{pH}$ was not strongly associated with lightness, suggesting that these traits are controlled by independent genetic mechanisms. However, ultimate meat $\mathrm{pH}$ seemed able to influence the meat lightness. The genetic selection for $\mathrm{pH}_{\mathrm{u}}$, hence, could reduce $\mathrm{L}^{*}$, improving this attribute for the consumer because the meat lightness indicates its paleness, which is one of the main factors that could prejudice the acceptance of poultry meat by the consumer (Fletcher, 1999).
The highly negative correlations among $\mathrm{pH}_{\mathrm{i}}$ and DL, TL, and TCL $(-0.40 \pm 0.089,-0.75 \pm 0.125$, and $-0.58 \pm 0.169$, respectively) was expected (Offer and Knight, 1988), in that a lower initial $\mathrm{pH}$ can lead to protein denaturation and consequently reduce the water holding capacity of meat. $\mathrm{As}_{\mathrm{pH}}$ was also exhibited a strong negative correlation with DL, TL, and TCL ( $r g-0.69 \pm 0.132,-0.83 \pm 0.075$, and $-0.42 \pm 0.128$ ), any increase in $\mathrm{pH}$ measures would reduce water holding capacity, confirming that the meat water holding capacity is genetically dependent on $\mathrm{pH}$ decreases in the analyzed line. In broilers, a negative association among meat $\mathrm{pH}$ measures and drip loss was also described by Le Bihan-Duval et al. (2001). The genetic selection for $\mathrm{pH}_{\mathrm{i}}$ or $\mathrm{pH}_{\mathrm{u}}$ could, therefore, prevent or reduce drip loss in the meat, which could be of interest to processing industry because drip loss brings great losses for this industry (Anthony, 1998; Sosnicki et al., 1988). The genetic selection for $\mathrm{pH}_{\mathrm{i}}$ or $\mathrm{pH}_{\mathrm{u}}$ could also prevent or reduce DL, TL and TCL in the studied male broiler line.

The trait $\mathrm{R}_{1}$ had a negative association with $\mathrm{pH}_{\mathrm{i}}$ and $\mathrm{pH}_{\mathrm{u}}(\mathrm{rg}$ $-0.64 \pm 0.316$, and $-0.73 \pm 0.170$, respectively), indicating that a low $\mathrm{pH}_{\mathrm{i}}$ and a low $\mathrm{pH}_{\mathrm{u}}$ are associated with a high $\mathrm{pH}$ falling during the first $6 \mathrm{~h}$ after slaughtering, which suggested that those animals that start the rigor mortis process with lower $\mathrm{pHs}$ after slaughtering have a tendency to undergo substantial $\mathrm{pH}$ decreases over $6 \mathrm{~h}$ after slaughtering. Additionally, there was probably a protein denaturation during $6 \mathrm{~h}$ after slaughtering, what could lead to high $\mathrm{L}^{*}$ and DL because the genetic correlation between $\mathrm{R}_{1}$ and these traits were moderate to high $(0.67 \pm 0.237$, and 0.68 \pm 0.224 , respectively). Therefore, the protein denaturation $6 \mathrm{~h}$ after slaughtering could induce to a lower water holding capacity, what causes higher $\mathrm{L}^{*}$ and $\mathrm{DL}$. In contrast, $\mathrm{R}_{\mathrm{f}}$ was genetically and positively associated with TCL only ( $\operatorname{rg} 0.51 \pm 0.095)$, suggesting that the initial $\mathrm{pH}$ decrease during $6 \mathrm{~h}$ after slaughtering is more determinant of meat quality attributes than final $\mathrm{pH}$ decrease.

High drip, thawing and thawing-cooking losses, due to extended $\mathrm{pH}$ decreases, may decrease the meat tenderness (Offer and Knight, 1988), and this situation is confirmed in the current study by the positive genetic correlation estimates obtained among SF and DL, TL, and TCL $(0.68 \pm 0.134,0.67 \pm 0.070$, and $0.51 \pm 0.095$, respectively). This association corresponds to the process reported by Fletcher (1999), in which the meat tenderness is influenced by water loss, and the higher the water content in meat is, the higher its tenderness is, and this influence is due to genetic factors, according to this study.

Table 3 - Estimates of genetic correlations ( \pm SE) among performance, carcass, and meat quality traits.

\begin{tabular}{llllllllllcc}
\hline Traits $^{1}$ & $\mathrm{pH}_{\mathrm{i}}$ & $\mathrm{pH}_{\mathrm{u}}$ & $\mathrm{R}_{\mathrm{i}}$ & $\mathrm{R}_{\mathrm{f}}$ & $\mathrm{L}^{*}$ & $\mathrm{a}^{*}$ & $\mathrm{~b}^{*}$ & $\mathrm{DL}$ & $\mathrm{TL}$ & TCL & SF \\
US & $0.38 \pm$ & $0.06 \pm$ & $0.56 \pm$ & $0.64 \pm$ & $0.33 \pm$ & $0.08 \pm$ & $0.28 \pm$ & $0.11 \pm$ & $0.31 \pm$ & $-0.24 \pm$ & $0.38 \pm$ \\
& 0.324 & 0.139 & 0.217 & 0.269 & 0.164 & 0.184 & 0.090 & 0.196 & 0.168 & 0.063 & 0.168 \\
$\mathrm{SBW}$ & $0.07 \pm$ & $-0.13 \pm$ & $-0.16 \pm$ & $0.56 \pm$ & $-0.06 \pm$ & $0.23 \pm$ & $0.26 \pm$ & $0.08 \pm$ & $0.16 \pm$ & $-0.04 \pm$ & $0.05 \pm$ \\
& 0.301 & 0.125 & 0.273 & 0.702 & 0.093 & 0.175 & 0.189 & 0.223 & 0.163 & 0.197 & 0.144 \\
EBW & $0.05 \pm$ & $-0.06 \pm$ & $-0.12 \pm$ & $0.98 \pm$ & $0.04 \pm$ & $0.27 \pm$ & $0.43 \pm$ & $0.02 \pm$ & $0.22 \pm$ & $-0.05 \pm$ & $0.08 \pm$ \\
& 0.355 & 0.081 & 0.316 & 1.243 & 0.073 & 0.175 & 0.166 & 0.209 & 0.153 & 0.193 & 0.145 \\
BRT & $0.47 \pm$ & $-0.05 \pm$ & $0.32 \pm$ & $0.84 \pm$ & $0.11 \pm$ & $0.07 \pm$ & $0.42 \pm$ & $0.14 \pm$ & $0.20 \pm$ & $-0.42 \pm$ & $0.08 \pm$ \\
& 0.138 & 0.125 & 0.162 & 0.302 & 0.084 & 0.125 & 0.152 & 0.221 & 0.129 & 0.119 & 0.138 \\
LEG & $0.17 \pm$ & $-0.18 \pm$ & $-0.03 \pm$ & $0.86 \pm$ & $0.06 \pm$ & $0.18 \pm$ & $0.25 \pm$ & $-0.10 \pm$ & $0.10 \pm$ & $0.19 \pm$ & $0.06 \pm$ \\
& 0.051 & 0.102 & 0.206 & 1.590 & 0.034 & 0.146 & 0.167 & 0.129 & 0.098 & 0.134 & 0.143 \\
\hline
\end{tabular}

${ }^{1} \mathrm{pH}_{\mathrm{i}}=$ initial $\mathrm{pH} ; \mathrm{pH}_{\mathrm{u}}=$ ultimate $\mathrm{pH} ; \mathrm{R}_{\mathrm{i}}=$ initial range of $\mathrm{pH}$ fall; $\mathrm{R}_{\mathrm{f}}=$ final range of $\mathrm{pH}$ fall; $\mathrm{L}^{*}=$ lightness; $\mathrm{a}^{*}=$ redness; $\mathrm{b}^{*}=$ yellowness; $\mathrm{DL}=$ drip loss; TL $=$ thawing loss; TCL $=$ thawing-cooking loss; $\mathrm{SF}=$ shear force; US = ultrasound record of pectoral muscle depth; SBW = slaughter BW; EBW = eviscerated BW; BRT = breast weight; LEG = leg weight. 
Traits $\mathrm{pH}_{\mathrm{i}}$ and $\mathrm{pH}_{\mathrm{u}}$ were negatively genetically associated with SF ( $\mathrm{rg}-0.62 \pm 0.170$, and $-0.63 \pm 0.094$, respectively) and the selection for these $\mathrm{pH}$ measures could also improve the meat tenderness, which could be of interest for the poultry industry because tenderness is an attribute that could cause consumer to reject meat (Li et al., 2001). TL, TCL and SF were genetically and positively associated with $L^{*}(\operatorname{rg} 0.37 \pm 0.093,0.40 \pm 0.101$, and $0.59 \pm 0.113$, respectively). The genetic selection against $\mathrm{L}^{*}$ could, then, be able to decrease TL and TCL, in addition to SF, which could be of interest to the poultry industry. Furthermore, $\mathrm{L}^{*}$ measurements at industrial slaughtering line could be easily implemented, because it is a simple and fast measure, which could be obtained with a portable equipment. The use of color parameter could be interesting for the poultry industry as a selection criterion.

PSE meat could not be identified in this male broiler line based on the results obtained because this condition depends on the association among initial $\mathrm{pH}$, lightness and water holding capacity of the meat, according to Swatland (1995), Qiao et al. (2001), Olivo and Shimokomaki (2006) and Barbut (2009). Many factors affect muscle color and the literature shows substantial differences in research relative to the definition of pale and normal poultry muscles (Smith and Northcutt, 2009), and the PSE syndrome should be evaluated by some degree of paleness and also reduced water-holding capacity, and increased drip loss. Also, there was no expressive genetic association between $\mathrm{pH}_{\mathrm{i}}$ and $\mathrm{L}^{*}$ in this study, whereas $\mathrm{R}_{1}$ was associated with $\mathrm{L}^{*}$; however we can not conclude about the presence of the PSE syndrome in this population founded on a measure of $6 \mathrm{~h}$ after slaughtering, since the literature presents the PSE syndrome as a condition that occurs just after slaughtering, when the carcass temperature is still high (Barbut, 1997, 2009; Smith and Northcutt, 2009).

The genetic association between US and $\mathrm{pH}_{\mathrm{i}}(\operatorname{rg} 0.38 \pm$ 0.324 ) presented a high standard-error; however, direct selection for higher BRT would increase $\mathrm{pH}_{\mathrm{i}}$ because the genetic correlation between these traits was moderate to high $(0.47 \pm 0.138)$. Therefore, the glycolytic potential of the muscle cells could not be disfavored by the increase of breast meat in this line, what would be expected, according to Solomon et al. (1998). These estimates disagree with Dransfield and Sosnicki (1999), that suggest that the selection for higher breast weight tends to reduce initial meat $\mathrm{pH}$ and consequently release a greater PSE meat frequency. The selection for US and BRT would not be expected to influence $\mathrm{pH}_{\mathrm{u}}$ which are nearly uncorrelated ( $\mathrm{rg} 0.06$ \pm 0.139 , and $-0.05 \pm 0.125$, respectively). Previous studies have also found that $\mathrm{pH}_{\mathrm{u}}$ was correlated neither with BRT nor with breast yield (Le Bihan-Duval et al., 1999, 2001).

Significant genetic associations were found between US and BRT and $R_{f}$ (rg $0.64 \pm 0.269$, and $0.84 \pm 0.302$, respectively), as well as between US and $\mathrm{R}_{1}(\mathrm{rg} 0.56 \pm 0.217)$. Thus, the selection for higher BRT, despite increasing $\mathrm{pH}_{\mathrm{i}}$, tends to augment $\mathrm{pH}$ decreases at $24 \mathrm{~h}$. The selection for US tends to increase $\mathrm{pH}$ fall at 6 and 24 h, which would not affect other meat quality attributes. Both US and BRT were uncorrelated with color parameters $\mathrm{L}^{*}$ and $\mathrm{a}^{*}(\operatorname{rg} 0.07 \pm 0.125$ to $0.33 \pm 0.164)$, but BRT was moderately to highly correlated with $\mathrm{b}^{*}$ ( $\left.\mathrm{rg} 0.42 \pm 0.152\right)$. Selection for BRT would therefore increase yellowness, but not the redness or lightness of the meat. Then, the use of these selection criteria by industry would not affect the paleness of the meat, which is important to the consumers. The genetic correlation estimate found for BRT and L* was similar to those reported between $L^{*}$ and breast yield (Le Bihan-Duval et al., 1999, 2001), but it was different from others that had reported for broilers between $L^{*}$ and breast weight (Le Bihan-Duval et al., 1999), which was moderate. The genetic correlation estimate found between BRT and $\mathrm{a}^{*}$ was low and differed from those reported for poultry for breast weight and breast yield, which were negative (Le BihanDuval et al., 1999, 2001, 2003). Furthermore, the moderate positive estimate obtained for BRT and $\mathrm{b}^{*}$ diverged from those reported by Le Bihan-Duval et al. $(1999,2001,2003)$ in poultry for breast weight and breast yield, which were negative. EBW was also genetically associated with $\mathrm{b}^{*}(\operatorname{rg} 0.43 \pm 0.166)$.

The selection for US and BRT could not affect DL, and TL, since these traits are not correlated, since the genetic correlations among these traits were weak $(\operatorname{rg} 0.11 \pm 0.196$ to 0.31 $\pm 0.168)$. However, the direct selection for BRT could decrease TCL because the genetic correlation between these traits is moderate and negative $(-0.42 \pm 0.119)$, restating the tendency of a favorable association between the quantity of meat in breast and the protein denaturation or also the water holding capacity of meat in the studied broilers. A low genetic association between water holding capacity and breast yield in broilers has already been reported (Le Bihan-Duval et al., 2001) as has a negative correlation between breast yield and drip and thawing-cooking losses (Le Bihan-Duval et al., 2008). All these results diverged from Dransfield and Sosnicki (1999), in which the selection for higher breast weight tends to increase the incidence of PSE condition in broiler meat, and, consequently, the water holding capacity of meat. Nevertheless, there was a moderate genetic correlation association between US and SF $(0.38 \pm 0.168)$. Thus, the selection for higher US could potentially increase SF, even though the meat shear force is reported as strictly related to water holding capacity (Fletcher, 1999) or inversely correlated with breast yield (Le Bihan-Duval et al., 2008).

Direct selection for SBW would not be expected to affect $\mathrm{pH}_{\mathrm{i}}, \mathrm{pH}_{\mathrm{u}}, \mathrm{R}_{\mathrm{i}}$, and $\mathrm{R}_{\mathrm{f}}$ based on the genetic correlations between these traits (-0.16 \pm 0.273 to $0.56 \pm 0.702)$. These associations were similar to those already reported (Le Bihan-Duval et al., 1999, 2001). There was a low genetic association between SBW and the color parameters $(-0.06 \pm 0.093$ to $0.26 \pm 0.189)$. Thus, the direct selection for SBW would not be expected to modify $\mathrm{L}^{*}, \mathrm{a}^{*}$ or $\mathrm{b}^{*}$ in the line analyzed. An increase in $\mathrm{L}^{*}$, which could prejudice the acceptance of poultry meat by the consumer, should not be a concern for the poultry industry if its selection is based only on live BW. Previous studies have also found low or inverse genetic association between BW and color parameters (Le Bihan-Duval et al., 1999, 2001), except for a high association between BW and L* (Le Bihan-Duval et al., 1999). The selection for higher SBW would not modify DL, TL, TCL, and SF because of the absence of a genetic association with these traits $(\mathrm{rg}-0.04 \pm 0.197$ to $0.16 \pm 0.163)$. The genetic correlation estimates among these traits were low or presented high standard-errors, which was also the case for LEG and meat quality traits. In other words, body weight and carcass measurements are not meat quality indicators in this male broiler line, except for breast meat. 
The previously described differences between these results and those found in literature could most likely be explained by the differences in the methods of recording $\mathrm{pH}$, the genotype used, the time of feed withdrawal before slaughtering, the necessity of transportation, and the general experimental conditions, which could cause divergences in the estimates of (co)variance components.

The direct selection for performance and carcass traits in the male broiler line analyzed did not affect the meat quality attributes in this study, since the genetic correlations among these traits were generally weak. BRT presented the most favorable genetic associations with meat quality attributes among all the performance and carcass traits studied because the direct selection for this trait could increase $\mathrm{pH}_{\mathrm{i}}$, and reduce TCL, and its use as selection criterion may be recommended to improve thawing-cooking losses in this line.

Selection for $\mathrm{pH}_{\mathrm{u}}$ or against $\mathrm{L}^{*}$ in the line analyzed could be adopted in this selection program because these traits are the most able to respond to selection among all meat quality traits. This selection could improve TL, TCL and SF, in addition to the improvement in DL attributed to $\mathrm{pH}_{\mathrm{u}}$ only. Moreover, $\mathrm{L}^{*}$ is a measure that can be easily assessed in an industrial slaughtering line, and it could be manipulated to improve meat color and tenderness, as well as to improve the water holding capacity of the meat after thawing and cooking. Other variable genetic associations among meat quality, and performance, and carcass traits were found; nevertheless, their genetic correlations were low or near to zero. These estimates also had low reliabilities because their standard-errors were high, which was probably due to the low number of records for the subclasses in the two-trait analysis.

Breast weight is a favorable carcass selection criterion for meat quality attributes in the analyzed broiler line because selection for this trait can be used to improve initial $\mathrm{pH}$ and thawingcooking losses of meat. The direct selection for ultrasound records of pectoral muscle depth may affect the tenderness of the meat in this line, and the use of this selection criterion should be re-evaluated if tenderness becomes a selection objective. The $\mathrm{pH}_{\mathrm{u}}$ or $\mathrm{L}^{*}$ could also be favorable selection criteria for the poultry industry to achieve improvements in meat quality because they are able to respond to selection. Both are associated with the water holding capacity of the meat, while $\mathrm{L}^{*}$ was the most easily measured on the industrial slaughtering line.

\section{Acknowledgements}

To FAPESP - The State of São Paulo Research Foundation - for the scholarship granted.

\section{References}

Anthony, N.B. 1998. A review of genetic practices in poultry: efforts to improve meat quality. Journal of Muscle Foods 9: 25-33.

Avisite. 2010. Statistics and prices. Available at: http://www.avisite.com.br/ economia/estatistica.asp?acao=carnefrango [Accessed Jan. 20, 2010] (in Portuguese).

Barbut, S. 1997. Problem of pale soft exudative meat in broiler chickens. British Poultry Science 38: 355-358.

Barbut, S. 2009. Pale, soft, and exudative poultry meat: reviewing ways to manage at the processing plant. Poultry Science 88: 1506-1512.
Bressan, M.C.; Beraquet, N.J. 2004. Pre-chilling and chilling treatments on poultry breast meat quality. Ciência e Tecnologia de Alimentos 24: 230235 (in Portuguese, with abstract in English).

Comission International de l'Eclairage [CIE]. 1976. Colorimetry. 2ed., CIE, Vienna, Austria.

Dransfield, E.; Sosnicki, A.A. 1999. Relationship between muscle growth and poultry meat quality. Poultry Science 78: 743-746.

Fernandez, X.; Santé. V.; Baeza, E.; Le Bihan-Duval, E.; Berri, C.; Rémignon, H.; Babilé, R.; Le Pottier, G.; Astruc, T. 2002. Effects of the rate of muscle post mortem $\mathrm{pH}$ fall on the technological quality of turkey meat. British Poultry Science 43: 245-252.

Fletcher, D.L. 1999. Broiler breast meat color variation, $\mathrm{pH}$ and texture. Poultry Science 78: 1323-1327.

Galobart, J.; Moran, E.T. 2004. Freeze-thaw and cooking effects on broiler breast fillets with extreme initial L* values. Poultry Science 83: 2093-2097.

Groeneveld, E. 1997. VCE4 User's guide and reference manual. Institute of Animal Husbandry and Animal Behaviour, Federal Agricultural Research Centre, Neustad, Germany.

Honikel, K.O. 1998. Reference methods for the assessment of physical characteristics of meat. Meat Science 49: 447-457.

Larzul, C.P.; Gozne, J.; Talmanta, A.; Jacques, B.; Lefaucheur, L.; Ecolar, P.; Sellier, P.; Monin, G. 1999. Selection for reduced muscle glycolitic potential in Large White pigs. II. Correlated responses in meat quality and muscle compositional traits. Genetics Selection Evolution 31: 61-76.

Le Bihan-Duval, E. 2004. Genetic variability within and between breeds of poultry technological meat quality. World's Poultry Science Association 60: 331-340.

Le Bihan-Duval, E.; Berri, C.; Baeza, E.; Mollet, N.; Beaumont, C. 2001. Estimation of the genetic parameters of meat characteristics and their genetic correlations with grow and body composition in a experimental broiler line. Poultry Science 80: 839-843.

Le Bihan-Duval, E.; Berri, C.; Baeza, E.; Santé, V.; Astruc, T.; Rémignon, H.; Le Portier, G.; Bentley, J.; Beaumont, C.; Fernandez, X. 2003. Genetic parameters of meat technological quality traits in a grand-parental commercial line of turkey. Genetics Selection Evolution 35: 623-635.

Le Bihan-Duval, E.; Debut, M.; Berri, C.M.; Sellier, N.; Santé-Lhoutellier, V.; Jégo, Y.; Beaumont, C. 2008. Chicken meat quality: genetic variability and relationship with growth and muscle characteristics. BMC Genetics 9: 53.

Le Bihan-Duval, E.; Millet, N.; Rémignon, H. 1999. Broiler meat quality: effect of selection for increased carcass quality and estimates of genetic parameters. Poultry Science 78: 822-826.

Li, J.; Tan, I.; Shatadal, P. 2001. Classification of tough and tender beef by image texture analysis. Meat Science 57: 341-346.

Offer, G.; Knight, P. 1988. The structural basis of water-holding in meat: general principles and water uptake in meat processing. p. 63-171. In: Offer, G.; Knight, P. Developments in meat science. Elsevier, New York, NY, USA.

Olivo, R.; Shimokomaki, M. 2006. PSE meat in poultry. p. 95-103. In: Shimokomaki, M.; Olivo, R.; Terra, N.N.; Franco, B.D.G.M. News in science and technology of meat. Varela, São Paulo, SP, Brazil (in Portuguese).

Qiao, M.; Fletcher, D.L.; Smith, D.P.; Northcutt, J.K. 2001. The effect of broiler breast meat color on $\mathrm{pH}$ : moisture, water-holding capacity, and emulsification capacity. Poultry Science 80: 676-680.

Sams, A.R. 1999. Meat quality during processing. Poultry Science 78: 798803.

SAS Institute. 1999. Statistical Analysis System User's Guide. SAS Institute, Cary, NC, USA.

Smith, D.P.; Northcutt, J.K. 2009. Pale poultry muscle syndrome. Poultry Science 88: 1493-1496.

Solomon, M.B.; Van Laack, J.M.; Eastridge, J.S. 1998. Biophysical basis of pale, soft and exsudative (PSE) pork and poultry muscle: a review. Journal of Muscle Foods 9: 1-11.

Sosnicki, A.A.; Greaser, M.L.; Pietrzak, M.; Pospiech, E.; Sante, V. 1988. PSElike syndrome in breast muscle of domestic turkeys: a review. Journal of Muscle Foods 9: 13-23.

Swatland, H.J. 1995. On Line Evaluation of Meat. Technomic, Lancaster, UK.

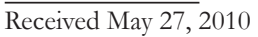

Accepted May 31, 2011 